\title{
Effect of Addition of Roselle Seed Flour on Color and Textural Properties of Cookies
}

\author{
Karma Bako Rimamcwe ${ }^{1}$, U.D. Chavan ${ }^{1 *}$, Ashok Kadlag ${ }^{2}$ and V.S. Wani ${ }^{3}$ \\ ${ }^{1}$ Department of Food Science and Technology, ${ }^{2}$ Department of Soil Science and Agricultural \\ Chemistry, ${ }^{3}$ Department of Statistics, Mahatma Phule Krishi Vidyapeeth, Rahuri, India \\ *Corresponding author
}

\begin{tabular}{|c|c|}
\hline & A B S T R A C T \\
\hline & $\begin{array}{l}\text { Colorimetric and texture profiles of cookies made from Roselle flour (RSF) and Roselle } \\
\text { Seed Oil (RSO) were studied. Commission Internationale de I' Exchange (CIE) L*a*b* }\end{array}$ \\
\hline $\begin{array}{l}\text { Ke y w or d s } \\
\text { Roselle, } \\
\text { Colorimetric, } \\
\text { Texture, Cookies }\end{array}$ & $\begin{array}{l}\text { coordinates a rectangular coordinate system was adopted for colorimetric studies to } \\
\text { establish the total color difference } \Delta \mathrm{E}^{*} \text {. A texturometer was used to measure the crushing, } \\
\text { cutting, and penetration force calculated at the entire area of cookie samples. Colorimetric } \\
\text { test showed cookie products becomes darker }\left(\mathrm{L}^{*}\right) \text {, less red }\left(\mathrm{a}^{*}\right) \text { and yellow }\left(\mathrm{b}^{*}\right) \text { with } \\
\text { inclusion of RSF and RSO at } 10 \%, 15 \%, 20 \%, 25 \% \text { and } 5 \%, 10 \%, 15 \%, 20 \%, 25 \%, 30 \%\end{array}$ \\
\hline Article Info & $\begin{array}{l}\text { for the treatments Sprouted Decorticated Roselle Seed Flour (SDRSF), Un-sprouted } \\
\text { Decorticated Roselle Seed Flour (UDRSF) and Roselle Seed Oil respectively. }\end{array}$ \\
\hline $\begin{array}{l}\text { Accepted: } \\
30 \text { March } 2018 \\
\text { Available Online: } \\
10 \text { April } 2018\end{array}$ & $\begin{array}{l}\text { Texturometer test showed crushing, cutting and penetration force needed to break the } \\
\text { cookies decreased with incorporation of RSF and RSO. The overall test results showed } \\
\text { that there was significant difference }(\mathrm{p}<0.05) \text { for both colorimetric and texture between } \\
\text { cookies made from the composite RSF blend and RSO when compared to cookies made }\end{array}$ \\
\hline
\end{tabular}

\section{Introduction}

All the estimated nutritional parameters based on amino acids composition showed that Roselle seed protein fractions and their isolates have a good nutritional quality and suggests their possible use as a supplementary protein source (Karma and Chavan, 2016). Fractions were found to have a high concentration of low molecular weight polypeptides, in contrast to wheat protein, gluten, with low biological and nutritional value (Lamacchia et al., 2014). The Roselle protein isolates and its fractions could have excellent applications for future product development by virtue of their nutritional and functional properties. This could add value to the existing uses of the plant and expand it cultivation. Further evaluation of saturated to unsaturated fatty acids in Roselle seed lipids 
(Karma and Chavan, 2016) corroborates Mohiuddin and Zaidi (1975) of 1:3 in contrast to widely acknowledged 1:2 ratio El-Adawy and Khalil (1994). Al-Wandawi et al., (1984) Roselle seed has eighteen amino acids with leucine as the most abundant essential amino acids followed by lysine. Al-Wandawi (2015) compared organic acid composition of different parts of the plants, results showed seeds pods having lesser oxalic acid contents (19.28\%) when compared to calyces (44.60 $\%)$, green leaves $(74.30 \%)$ and petioles $(86.77$ $\%)$ stating that healthy individuals can safely consume oxalic acid in moderation but those with kidney disorders, osteoporosis or rheumatoid arthritis are typically advised against even though there is no cause to be concerned. A dilute amount of oxalic acid can rapidly crack the casein in various dairy products; which gives Roselle seed a better superior quality for all round nutrition.

The oil profile of Roselle seed oil suggest beneficial use nutritionally and medically in lowering blood pressure and serum cholesterol (Savage, 2001; Enujiugba and Akanbi, 2008; Tounkara et al., 2011; Cissouma et al., 2013). El-Adawy and Khalil (1994) considered different cultivars of Roselle seeds in their study to have a high total carbohydrate content ranging from 36-38 \%, however on the contrary a study by Hainida et al., (2008), Karma and Chavan (2016), Karma et al., (2017a,b,c); discovered a lower carbohydrate content in the Roselle seeds. Roselle seeds flour in composite formulation with wheat flour reduced the carbohydrate and gluten contents (Karma and Chavan, 2016). Gluten constitutes a hazard for people with celiac disease (Humbert et al., 2006; Karma and Chavan, 2017).

The prevalent nutritional and chemical constituents of Roselle seeds four could impact on the physical attributes in composite formulations with other seeds flour in value added products; hence the objective of this study was to find the effect of addition of Roselle seed flour on color and textural properties of cookies.

\section{Materials and Methods}

\section{Materials}

Roselle (Hibiscus sabdariffa L.) and Wheat (Triticum aestivum spp.) seeds were sourced from the vegetable market in Ahmednagar, Maharashtra State, India and both were of local varieties. The various ingredients: Margarine, granulated sugar, salt, sodium bicarbonate and ammonium bicarbonate used for baking were all provided from the pilot bakery unit of the Department of Food Science and Technology, Mahatma Phule Agricultural University, Rahuri Ahmednagar District Maharashtra State India.

\section{Cleaning}

The seeds were cleaned by washing to separate poor quality seeds, adhering dust particles, stones, plant debris and dried carefully at ambient conditions under fan to preserve its nutritive value, packed in a HDPE bag and stored in a cool dry place until used.

\section{Germination}

The cleaned seeds were soaked for 6 hours to initiate the process of germination, after which the seeds were washed and allowed to drain. The drained seeds were then spread on a damped cloth in a perforated container with water sprinkled occasionally in a modified dark room to activate germination for a another 12 hour period at $70-85 \%$ relative humidity then gently washed and spread sparsely to dry under fan at ambient temperature to preserve its nutritive value, packed in a HDPE bag and stored in a cool dry place until used. 


\section{Equipments}

Laboratory scale hammer mill was used in milling the seed samples is available in the Department of Food Science and Technology, Post Graduate Institute Rahuri, Maharashtra State India.

\section{Pre-treatments}

The pre-treatments: Un-sprouted Whole Roselle Seeds Flour (UWRSF) as Control, Un-sprouted Decorticated Roselle Seed flour (UDRSF), Sprouted Whole Roselle Seed Flour (SWRSF) and Sprouted Decorticated Roselle Seed Flour (SDRSF); were prepared accordingly and packed separately in a HDPE bag and stored in a cool dry place until used.

\section{Cookie preparation}

The molded cookie was adopted for this study owing to its simplicity, Wikipedia (2016). The Cookie was prepared according to proposed method by Noor Aziah et al., (2012) with modification; using basic ingredients (Wani et al., 2015) to simplify critical investigations (Table 1).

\section{Sensory evaluation}

Sensory evaluation of sample cookies was done using Hedonic test on a 9 scale points based on appearance, flavor, crispiness, taste and overall acceptability from 20 semi trained panelists. See appendix 2 and 3 for sensory evaluation score card.

\section{Colour determination}

Colour difference of sample cookies compared to the standard sample was measured by a colour scanning machine (Premier Colour scan, Thane). The principle described by Konica (2016) was employed for this determination. The Commission Internationale de I'Eclairage (CIE), L*a*b* coordinates was adopted for this study. It provides reading in terms of $L^{*}, a^{*}$ and $b^{*}$. Where, luminance $\left(L^{*}\right)$ forms the vertical axis, which indicates lightness (+) to darkness (-). In the same way $a^{*}$ indicates redness $(+)$ to greenness $(-)$ and $b^{*}$ indicates yellowness (+) to blueness (-). The instrument was standardized before placing the sample by placing the standard cookie sample in the instrument. Once the instrument was standardised, it was ready to measure the colour. The sample was filled in the sample cup. The deviation $\left(\Delta \mathbf{E}^{8}\right)$ of the colour of the sample to standard was observed and recorded in the computer interface expressed using the equation:

$\Delta E^{8}=\sqrt{\left(\Delta b^{8}\right)^{2}+\left(\Delta a^{8}\right)^{2}+\left(\Delta a^{8}\right)^{2}}$

\section{Texture analysis of cookies}

Texture analysis of cookies was performed for cutting force, crushing force and penetration force using Universal Testing Machine (Shimadzu, Japan, Model No. AG-X, with $2500 \mathrm{~N}$ Capacity) Texturometer in the instrumentation laboratory of Dr. Annasaheb Shinde College of Agricultural Engineering and Technology, Department of Agricultural Process Engineering MPKV, Rahuri. Each cookie was placed on the loading cell and compressed. The conditions employed were as follows; cross head speed: $50 \mathrm{~mm} / \mathrm{min}$, maximum load cell force: $1 \mathrm{~kg}$ and compression: 75 per cent. The maximum force required to just break the cookies is the hardness. It was expressed in terms of Newton $(\mathrm{N})$.

\section{Statistical analysis}

All experiments were carried out in such a way that the degree of freedom remains more than 12 with suitable replications and treatments. Data obtained in the present study 
were analyzed by Completely Randomized Design (C.R.D.) design as given by Panse and Sukhatme (1967).

\section{Results and Discussion}

\section{Sensory evaluation of cookies}

Sensory study of cookies with the addition of varying percentages of Pretreated Roselle seeds flour and Oil were evaluated. Panels of 20 semi-trained human panelists were employed to test the cookie products and record effective responses based on 9 point hedonic scale to evaluate the attributes of appearance, flavour, taste, crispiness and overall acceptability. The results obtained were outlined in the tables (Table 2 to 4; Fig. 1).

\section{For Un-sprouted Decorticated Roselle Seed Flour (UDRSF)}

$\mathrm{UD}_{2}$ ranked the highest for overall acceptability of 8.6 , followed by $\mathrm{UD}_{3} 8.22$, $\mathrm{UD}_{0}$ 8.20, $\mathrm{UD}_{4}$ 8.14; while $\mathrm{UD}_{4}$ had the minimum score of 7.7 .

The result score for appearance ranged from 7.4 to 8.14 with $\mathrm{UD}_{0}$ being the most appealing to sight 8.14 and $\mathrm{UD}_{4}$ had the least 7.4. Results for flavour showed $\mathrm{UD}_{2}$ had 8.47 the highest while $\mathrm{UD}_{4}$ had 7.4 the lowest score (Table 2).

The score range for crispiness showed $\mathrm{UD}_{2}$ having the highest score 8.2 while $\mathrm{UD}_{4}$ had the least score 7.66. For taste attribute $\mathrm{UD}_{\mathrm{o}}$ had the highest 8.4 while $\mathrm{UD}_{4}$ had the least with a score of 7.58 .

The score for appearance, flavour, crispiness and taste showed that there was a significant difference $(p<0.05)$ between cookies made from the composite flour mix and wheat flour. $\mathrm{UD}_{2}(15-85 \%)$ formulation had the most superior quality attributes in the final baked products.

\section{For Un-sprouted Decorticated Roselle Seed Flour (SDRSF)}

$\mathrm{SD}_{2}$ ranked the highest for overall acceptability of 8.9 , followed by $\mathrm{SD}_{3} 8.27$, $\mathrm{SD}_{1}$ 8.14, $\mathrm{SD}_{0}$ 8.0; while $\mathrm{SD}_{4}$ had the minimum score of 7.75. The Score for appearance, flavour, crispiness and taste showed that there was a significant difference $(p<0.05)$ between cookies made from the composite flour mix and wheat flour (Table 3).

The score for appearance ranged from 7.56 to 8.26. $\mathrm{SD}_{0}$ ranked highest with 8.26 followed by $\mathrm{SD}_{2} 8.0, \mathrm{SD}_{3} 7.9, \mathrm{SD}_{1} 7.89$ and $\mathrm{SD}_{4}$ having the least score of 7.56. For flavour $\mathrm{SD}_{2}$ had the highest 8.45 while $\mathrm{SD}_{4}$ had the lowest 7.4. For crispiness $\mathrm{SD}_{2}$ had the highest 8.5 while $\mathrm{SD}_{4}$ had the lowest 7.99. For taste $\mathrm{SD}_{2}$ had the highest 8.5 while $\mathrm{SD}_{4}$ had the lowest 7.9.

The Score for appearance, flavour, crispiness and taste showed that there was a significant difference $(p<0.05)$ between cookies made from the composite flour mix and wheat flour. Cookie $\mathrm{SD}_{2}$ with formulation $15-85 \%$ had the most superior quality attributes in the final baked products.

\section{For Roselle Seed Oil (RSO)}

$\mathrm{RO}_{3}$ ranked the highest for overall acceptability of 8.3 , followed by $\mathrm{RO}_{2} 8.13$, $\mathrm{RO}_{1} 8.12, \mathrm{RO}_{0}$ and $\mathrm{RO}_{4} 8.0$ at per; $\mathrm{RO}_{6}$ 7.46; while $\mathrm{RO}_{6}$ had the minimum score of 6.47 . The score for appearance, flavour, crispiness and taste showed that there was a significant difference $(p<0.05)$ cookies made from replacing margarine with Roselle seed oil.

For appearance $\mathrm{RO}_{0}$ had the highest 8.30, while $\mathrm{RO}_{6}$ had the least 7.01. For flavour $\mathrm{RO}_{3}$ had the highest 8.42 while $\mathrm{RO}_{6}$ had the least score 6.9. For crispiness $\mathrm{RO}_{3}$ had the highest 8.63 while $\mathrm{RO}_{6}$ had the lowest 6.64. 
Fig.1 Preparation of cookies by adding roselle seeds flour

Hydrogenated vegetable fat

Mixing thoroughly with ground white sugar

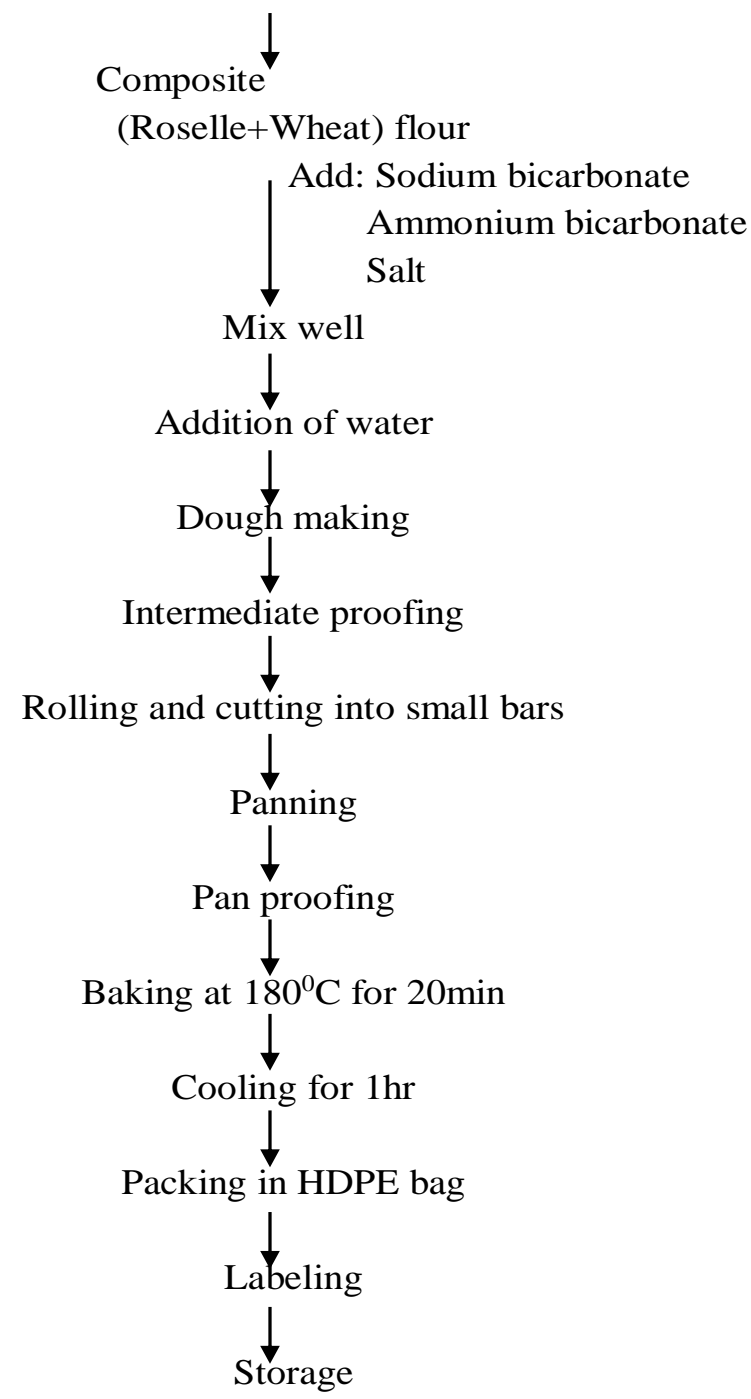

Table.1 Ingredients and composition for composite flour for cookies

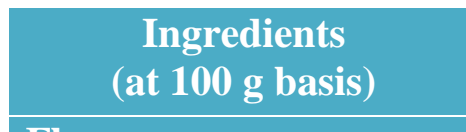

\begin{tabular}{|c|c|c|c|c|}
\hline \multirow{2}{*}{ Control } & \multicolumn{4}{|c|}{ Flour Replacement } \\
\hline 100 & $10 \%$ & $15 \%$ & $20 \%$ & $25 \%$ \\
\hline 40 & $10: 90$ & $15: 85$ & $20: 80$ & $25: 75$ \\
\hline 50 & 50 & 40 & 40 & 40 \\
\hline 0.5 & 0.5 & 0.5 & 0.5 & 0.5 \\
\hline 0.5 & 0.5 & 0.5 & 0.5 & 0.5 \\
\hline 20 & 20 & 20 & 20 & 20 \\
\hline 1 & 2 & 2 & 2 & 1 \\
\hline
\end{tabular}


Int.J.Curr.Microbiol.App.Sci (2018) 7(4): 3726-3737

Table.2 Organoleptic evaluation of cookies prepared from UDRSF

\begin{tabular}{|c|c|c|c|c|c|c|}
\hline $\begin{array}{l}\text { Sample } \\
\text { Code }\end{array}$ & Appearance & Flavour & Crispiness & Taste & $\begin{array}{c}\text { Overall } \\
\text { acceptability }\end{array}$ & Rank \\
\hline UDo & 8.14 & 7.78 & 8.78 & 8.40 & 8.20 & 3 \\
\hline$\overline{\mathrm{UD}_{1}}$ & 7.88 & 8.07 & 8.30 & 8.00 & 8.14 & 4 \\
\hline $\mathrm{UD}_{2}$ & 7.88 & 8.47 & 8.20 & 8.38 & 8.60 & 1 \\
\hline $\mathrm{UD}_{3}$ & 7.82 & 7.95 & 8.19 & 8.12 & 8.22 & 2 \\
\hline $\mathrm{UD}_{4}$ & 7.40 & 7.50 & 7.66 & 7.58 & 7.70 & 5 \\
\hline $\mathbf{S E}( \pm)$ & 0.02 & 0.03 & 0.02 & 0.02 & 0.01 & \\
\hline CD@5(\%) & 0.07 & 0.09 & 0.07 & 0.07 & 0.06 & \\
\hline $\mathrm{CV}(\%)$ & 0.62 & 0.79 & 0.53 & 0.54 & 0.46 & \\
\hline
\end{tabular}

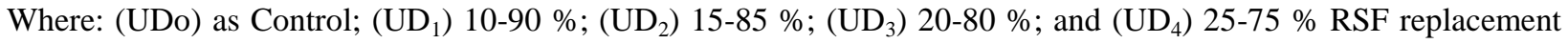
respectively.

Table.3 Organoleptic evaluation of cookies prepared from SDRSF

\begin{tabular}{|l|c|c|c|c|c|c|}
\hline Sample Code & Appearance & Flavour & Crispiness & Taste & Overall acceptability & Rank \\
\hline SD $_{0}$ & 8.26 & 7.70 & 8.14 & 8.00 & 8.00 & 4 \\
\hline SD $_{1}$ & 7.89 & 7.49 & 8.20 & 8.50 & 8.14 & 3 \\
\hline $\mathrm{SD}_{2}$ & $\mathbf{8 . 0 0}$ & $\mathbf{8 . 4 5}$ & $\mathbf{8 . 5 0}$ & $\mathbf{8 . 5 4}$ & $\mathbf{8 . 9 0}$ & $\mathbf{1}$ \\
\hline $\mathrm{SD}_{3}$ & 7.90 & 8.13 & 8.30 & 8.50 & 8.27 & 2 \\
\hline $\mathrm{SD}_{4}$ & 7.56 & 7.40 & 7.99 & 7.90 & 7.75 & 5 \\
\hline $\mathrm{SE}( \pm)$ & 0.004 & 0.02 & 0.02 & 0.02 & 0.004 & \\
\hline $\mathrm{CD}$ at5 \% & 0.01 & 0.06 & 0.06 & 0.05 & 0.01 & \\
\hline $\mathrm{CV}(\%)$ & 0.11 & 0.46 & 0.45 & 0.45 & 0.09 & \\
\hline
\end{tabular}

Where: $\left(\mathrm{SD}_{0}\right)$ as Control; $\left(\mathrm{SD}_{1}\right)$ 10-90 \%; $\left(\mathrm{SD}_{2}\right)$ 15-85 \%; $\left(\mathrm{SD}_{3}\right) 20-80 \%$; and $\left(\mathrm{SD}_{4}\right)$ 25-75 \% RSF replacement respectively.

Table.4 Organoleptic evaluation of cookies prepared from RSO

\begin{tabular}{|l|c|c|c|c|c|c|}
\hline $\begin{array}{l}\text { Sample } \\
\text { Code }\end{array}$ & Appearance & Flavour & Crispiness & Taste & $\begin{array}{c}\text { Overall } \\
\text { acceptability }\end{array}$ & Rank \\
\hline $\mathbf{R O}_{\mathbf{0}}$ & 8.30 & 8.10 & 8.20 & 8.00 & 8.00 & 4 \\
\hline $\mathbf{R O}_{\mathbf{1}}$ & 8.22 & 8.11 & 8.00 & 8.09 & 8.12 & 3 \\
\hline $\mathbf{R O}_{2}$ & 8.17 & 8.02 & 8.00 & 8.23 & 8.13 & 2 \\
\hline $\mathbf{R O}_{3}$ & $\mathbf{7 . 9 4}$ & $\mathbf{8 . 4 2}$ & $\mathbf{8 . 6 3}$ & $\mathbf{8 . 9 0}$ & $\mathbf{8 . 3 0}$ & $\mathbf{1}$ \\
\hline $\mathbf{R O}_{4}$ & 8.20 & 8.00 & 8.45 & 8.40 & 8.00 & 4 \\
\hline $\mathbf{R O}_{5}$ & 7.43 & 7.54 & 6.93 & 7.82 & 7.46 & 6 \\
\hline $\mathbf{R O}$ & 7.01 & 6.90 & 6.64 & 6.00 & 6.47 & 7 \\
\hline $\mathbf{S E}( \pm)$ & 0.004 & 0.02 & 0.04 & 0.03 & 0.02 & \\
\hline $\mathbf{C D}$ at 5 \% & 0.01 & 0.06 & 0.13 & 0.10 & 0.06 & \\
\hline $\mathbf{C V}(\%)$ & 0.13 & 0.57 & 1.35 & 1.05 & 0.65 & \\
\hline
\end{tabular}

Where: (ROo) as Control; $\left(\mathrm{RO}_{1}\right)$ 5-45 \%; $\left(\mathrm{RO}_{2}\right) 10-40 \%$; $\left(\mathrm{RO}_{3}\right)$ 15-35\%; $\left(\mathrm{RO}_{4}\right) 20-30 \%$; $\left(\mathrm{RO}_{5}\right) 25-25 \%$ and $\left(\mathrm{RO}_{6}\right)$ $30-20 \%$ RSO replacement respectively at 50\% standard recipe formulation 
Table.5 Effects of addition of *SDRSF on total colour difference of cookie

\begin{tabular}{|c|c|c|c|c|c|c|c|c|c|c|}
\hline \multirow{2}{*}{$\begin{array}{l}\text { Colour } \\
\text { Space }\end{array}$} & \multicolumn{5}{|c|}{ TREATMENTS FOR SDRSF COOKIES } & \multirow{2}{*}{$\begin{array}{c}\text { Delta of } \\
\text { Colour Space }\end{array}$} & \multicolumn{4}{|c|}{ TOTAL COLOUR DIFFERENCE } \\
\hline & Control & 10 & 15 & 20 & 25 & & 10 & 15 & 20 & 25 \\
\hline $\mathbf{L} *$ & 68.61 & 67.20 & 66.73 & 66.63 & 66.31 & $\Delta \mathrm{L}^{*}$ & -1.41 & -1.88 & -1.98 & -2.30 \\
\hline$a^{*}$ & 5.85 & 5.19 & 4.79 & 4.75 & 4.44 & $\Delta \mathrm{a}^{*}$ & -0.66 & -1.06 & -1.10 & -1.41 \\
\hline $\mathbf{b}^{*}$ & 24.22 & 20.65 & 19.58 & 19.42 & 18.53 & $\Delta \mathrm{b}^{*}$ & -3.57 & -4.64 & -4.80 & -5.69 \\
\hline $\mathbf{S E}( \pm)$ & 0.66 & 0.30 & 0.12 & 0.09 & 0.10 & $\Delta \mathbf{E}^{*}$ & 3.89 & 5.12 & 5.31 & 6.29 \\
\hline CDat5 (\%) & 1.96 & 0.86 & 0.35 & 0.28 & 0.30 & \multicolumn{5}{|c|}{ Comments } \\
\hline \multirow[t]{3}{*}{$\mathrm{CV}(\%)$} & 2.84 & 1.36 & 0.56 & 0.44 & 0.48 & $\Delta \mathrm{L}^{*}$ & Darker & Darker & Darker & Darker \\
\hline & & & & & & $\Delta \mathrm{a}^{*}$ & $<$ Red & $<$ Red & $<$ Red & $<$ Red \\
\hline & & & & & & $\Delta \mathrm{b}^{*}$ & $<$ Yellow & $<$ Yellow & $<$ Yellow & $<$ Yellow \\
\hline
\end{tabular}

*Spouted Decorticated Roselle Seed Flour (SDRSF); each value is an average of seven determinations.

Table.6 Effects of addition of *UDRSF on total colour difference of cookie

\begin{tabular}{|c|c|c|c|c|c|c|c|c|c|c|}
\hline \multirow{2}{*}{$\begin{array}{l}\text { Colour } \\
\text { Space }\end{array}$} & \multicolumn{5}{|c|}{ TREATMENTS FOR UDRSF COOKIES } & \multirow{2}{*}{$\begin{array}{c}\text { Delta of } \\
\text { Colour Space }\end{array}$} & \multicolumn{4}{|c|}{ TOTAL COLOUR DIFFERENCE } \\
\hline & Control & 10 & 15 & 20 & 25 & & 10 & 15 & 20 & 25 \\
\hline $\mathbf{L} *$ & 68.61 & 67.58 & 67.06 & 66.52 & 66.42 & $\Delta \mathrm{L}^{*}$ & -1.03 & -1.55 & -2.09 & -2.20 \\
\hline $\mathbf{a}^{*}$ & 5.85 & 5.73 & 5.57 & 5.09 & 4.61 & $\Delta \mathrm{a}^{*}$ & -0.12 & -0.28 & -0.76 & -1.24 \\
\hline $\mathbf{b}^{*}$ & 24.22 & 21.81 & 20.69 & 19.01 & 18.96 & $\Delta \mathrm{b}^{*}$ & -2.41 & -3.53 & -5.21 & -5.26 \\
\hline $\mathrm{SE}( \pm)$ & 0.66 & 0.40 & 0.59 & 1.01 & 0.68 & $\Delta \mathbf{E}^{*}$ & 2.62 & 3.87 & 5.66 & 5.84 \\
\hline CDat5 (\%) & 1.96 & 1.20 & 1.76 & 3.01 & 2.01 & \multicolumn{5}{|c|}{ Comments } \\
\hline CV (\%) & 2.84 & 1.80 & 2.70 & 4.75 & 3.19 & $\Delta \mathrm{L}^{*}$ & Darker & Darker & Darker & Darker \\
\hline & & & & & & $\Delta \mathrm{a}^{*}$ & $<$ Red & $<$ Red & $<$ Red & $<$ Red \\
\hline & & & & & & $\Delta \mathrm{b}^{*}$ & $<$ Yellow & $<$ Yellow & $<$ Yellow & $<$ Yellow \\
\hline
\end{tabular}

*Un-sprouted Decorticated Roselle Seed Flour (UDRSF); each value is an average of seven determinations. 
Table.7 Effects of addition of RSO on total colour difference of cookie

\begin{tabular}{|c|c|c|c|c|c|c|c|c|c|c|c|c|c|c|}
\hline \multirow{2}{*}{$\begin{array}{l}\text { Colour } \\
\text { Space }\end{array}$} & \multicolumn{7}{|c|}{ TREATMENTS FOR RSO COOKIES } & \multirow{2}{*}{$\begin{array}{l}\text { Delta of } \\
\text { Colour } \\
\text { Space }\end{array}$} & \multicolumn{6}{|c|}{ TOTAL COLOUR DIFFERNCE } \\
\hline & Control & 5 & 10 & 15 & 20 & 25 & 30 & & 5 & 10 & 15 & 20 & 25 & 30 \\
\hline $\mathbf{L} *$ & 68.61 & 68.27 & 68.21 & 68.20 & 67.80 & 67.77 & 67.55 & $\Delta \mathrm{L}^{*}$ & -0.34 & -0.41 & -0.42 & -0.81 & -0.84 & -1.06 \\
\hline$a^{*}$ & 5.85 & 5.67 & 5.47 & 4.99 & 4.90 & 4.68 & 4.25 & $\Delta \mathrm{a}^{*}$ & -0.17 & -0.38 & -0.86 & -0.95 & -1.17 & -1.60 \\
\hline $\mathbf{b}^{*}$ & 24.22 & 23.51 & 23.44 & 23.39 & 22.30 & 22.26 & 21.17 & $\Delta \mathrm{b}^{*}$ & -0.71 & -0.78 & -0.83 & -1.92 & -1.96 & -3.05 \\
\hline $\mathrm{SE}( \pm)$ & 0.66 & 0.06 & 0.16 & 0.06 & 0.08 & 0.10 & 0.25 & $\Delta \mathbf{E}^{*}$ & 0.80 & 0.96 & 1.26 & 2.29 & 2.43 & 3.60 \\
\hline $\begin{array}{l}\text { CD@5 } \\
(\%)\end{array}$ & 1.96 & 0.17 & 0.46 & 0.17 & 0.25 & 0.29 & 0.74 & \multicolumn{7}{|c|}{ Comments } \\
\hline CV (\%) & 2.84 & 0.25 & 0.68 & 0.24 & 0.37 & 0.44 & 1.13 & $\Delta \mathrm{L}^{*}$ & Darker & Darker & Darker & Darker & Darker & Darker \\
\hline & & & & & & & & $\Delta \mathrm{a}^{*}$ & $<\operatorname{Red}$ & $<$ Red & $<\operatorname{Red}$ & $<\operatorname{Red}$ & $<\operatorname{Red}$ & $<$ Red \\
\hline & & & & & & & & $\Delta \mathrm{b}^{*}$ & $\begin{array}{c}<\text { Yello } \\
\text { W }\end{array}$ & $\begin{array}{l}<\text { Yello } \\
\mathrm{w}\end{array}$ & $\begin{array}{l}<\text { Yello } \\
\mathrm{w}\end{array}$ & $\begin{array}{l}<\text { Yello } \\
\text { w }\end{array}$ & $\begin{array}{l}<\text { Yello } \\
\mathrm{w}\end{array}$ & $\begin{array}{l}<\text { Yello } \\
\mathrm{w}\end{array}$ \\
\hline
\end{tabular}

*Roselle Seed Oil (RSO); each value is an average of seven determinations. 
Table.8 Effect of incorporating SDRSF on the texture of cookies

\begin{tabular}{|l|c|c|c|}
\hline \multicolumn{1}{|c|}{ Treatment } & $\begin{array}{c}\text { Crushing Force } \\
(\mathbf{N})\end{array}$ & $\begin{array}{c}\text { Cutting Force (N) } \\
\text { Control }\end{array}$ & $\begin{array}{c}\text { Penetration Force } \\
(\mathbf{N})\end{array}$ \\
\hline SDRSF 10-90 & 69.13 & 78.18 & 39.60 \\
\hline SDRSF 15-85 & 64.15 & 60.66 & 26.06 \\
\hline SDRSF 20-80 & 55.50 & 49.83 & 22.84 \\
\hline SDRSF 10-90 & 51.03 & 41.70 & 20.76 \\
\hline SE( \pm () & 45.03 & 35.58 & 20.52 \\
\hline CD at5 $(\%)$ & 0.56 & 0.52 & 0.41 \\
\hline CV $(\%)$ & 1.70 & 1.58 & 1.24 \\
\hline
\end{tabular}

Each value is an average of four determinations

Table.9 Effect of incorporating UDRSF on the texture of cookies

\begin{tabular}{|l|c|c|c|}
\hline \multicolumn{1}{|c|}{ Treatment } & $\begin{array}{c}\text { Crushing Force } \\
(\mathbf{N})\end{array}$ & $\begin{array}{c}\text { Cutting Force (N) } \\
\text { Control }\end{array}$ & $\begin{array}{c}\text { Penetration Force } \\
(\mathbf{N})\end{array}$ \\
\hline UDRSF 10-90 & 69.13 & 78.18 & 39.60 \\
\hline UDRSF 15-85 & 58.90 & 77.20 & 27.01 \\
\hline UDRSF 20-80 & 38.29 & 63.86 & 26.06 \\
\hline UDRSF 25-75 & 26.47 & 52.66 & 22.68 \\
\hline SE $( \pm)$ & 22.10 & 52.35 & 21.68 \\
\hline CD at5 $(\%)$ & 0.37 & 0.41 & 0.52 \\
\hline CV $(\%)$ & 1.10 & 1.23 & 1.55 \\
\hline
\end{tabular}

Each value is an average of four determinations

Table.10 Effect of incorporating RSO on the texture of cookies

\begin{tabular}{|l|c|c|c|}
\hline \multicolumn{1}{|c|}{ Treatment } & $\begin{array}{c}\text { Crushing Force } \\
(\mathbf{N})\end{array}$ & $\begin{array}{c}\text { Cutting Force (N) } \\
\text { Control }\end{array}$ & $\begin{array}{c}\text { Penetration Force } \\
(\mathbf{N})\end{array}$ \\
\hline RSO 5-45 & 69.13 & 78.18 & 39.60 \\
\hline RSO 10-40 & 60.18 & 56.53 & 26.06 \\
\hline RSO 15-35 & 58.18 & 52.24 & 25.51 \\
\hline RSO 20-30 & 46.23 & 44.85 & 24.67 \\
\hline RSO 25-25 & 42.89 & 42.73 & 21.09 \\
\hline RSO 30-20 & 38.46 & 38.37 & 18.75 \\
\hline SE( \pm ) & 27.04 & 35.47 & 16.65 \\
\hline CD at5 (\%) & 0.31 & 0.48 & 0.19 \\
\hline CV (\%) & 0.95 & 1.47 & 0.57 \\
\hline
\end{tabular}

Each value is an average of four determinations

NB: Treatments details as: SDRSF (Sprouted Decorticated Roselle Seed Flour); UDRSF (Un-sprouted Decorticated Roselle Seed Flour); RSO (Roselle Seed Oil). 
For taste $\mathrm{RO}_{6}$ had the highest 8.9 while $\mathrm{RO}_{6}$ had the lowest 6.0 score reason could be that the panelists are not use to the aroma and taste of Roselle seed oil since the oil is novel, as it is not widely known.

The score for appearance, flavour, crispiness and taste showed that there was a significant difference $(p<0.05)$ between cookies made from substituting margarine with Roselle seed oil and control with just margarine. Cookie $\mathrm{RO}_{3}$ with formulation 15-35\% had the most superior quality attributes and acceptability in the overall final baked products.

\section{Colour determination of cookie}

Colorimetry is the technique used to identify colour difference between samples and how they differ from standard. No matter how close two samples look the same, slight difference may be found when evaluated with a colour measurement instrument.

The colour differences between cookie samples were studied using the CIE L* a* $b^{*}$ coordinates a rectangular coordinate system defined by Commission Internationale de I' Eclairage (CIE), the $\mathrm{L}^{*} \mathrm{a}^{*} \mathrm{~b}^{*}$ colour space was modeled after a colour-opponent theory stating that two colours cannot be red and green at the same time. Where $\mathrm{L}^{*}$ indicates lightness, $\mathrm{a}^{*}$ is the red/green coordinates, and $b^{*}$ is the yellow/blue coordinate. Deltas for $\mathrm{L}^{*}\left(\Delta \mathrm{L}^{*}\right), \mathrm{a}^{*}$ $\left(\Delta \mathrm{a}^{*}\right)$ and $\mathrm{b}^{*}\left(\Delta \mathrm{b}^{*}\right)$ may be positive $(+)$ or negative (-). The total difference, Delta $\mathrm{E}\left(\Delta \mathrm{E}^{*}\right)$ is however always positive. Where:

$\Delta \mathrm{L}^{*} \quad\left(\mathrm{~L}^{*}\right.$ sample minus $\mathrm{L}^{*}$ standard $)=$ difference in lightness and darkness $(+=$ lighter, - = darker).

$\Delta \mathrm{a}^{*}(\mathrm{a} *$ sample minus $\mathrm{a} *$ standard $)=$ difference in red and green $(+=$ redder, $-=$ greener $)$.

$\Delta \mathrm{b}^{*}\left(\mathrm{~b}^{*}\right.$ sample minus $\mathrm{b}^{*}$ standard $)=$ difference in yellow and blue $(+=$ yellower, $-=$ bluer $)$. And,

$\Delta \mathrm{E}^{*}=$ Total Colour Difference.
The colour difference between all three coordinates was calculated using the formula (Eq. 19 section 3.2.10.2.4.).

$\Delta \mathbf{E}^{8}=\sqrt{\left(\Delta \mathbf{L}^{8}\right)^{2}+\left(\Delta \mathbf{a}^{8}\right)^{2}+\left(\Delta \mathbf{a}^{8}\right)^{2}}$

The results obtained are as shown in Table 4 to 7. The results showed that cookie products becomes darker $\left(\mathrm{L}^{*}\right)$, less red $\left(\mathrm{a}^{*}\right)$ and less yellow ( $\left.b^{*}\right)$ with inclusion of Roselle seed flours and oil in at $10 \%, 15 \%, 20 \%, 25 \%$ and $5 \%, 10 \%, 15 \%, 20 \%, 25 \%, 30 \%$ for the pair of SDRSF, UDRSF and RSO respectively. The results showed that there was a significant difference $(p<0.05)$ between cookies made from Roselle seed flour blends, Roselle seed oil and wheat flour as control respectively.

The summary of the total colour difference $\left(\Delta \mathrm{E}^{*}\right)$ for selected cookies in sensory evaluation Table 5 to Table 7 showed: SDRSF 15-85 having the highest colour difference with $\Delta \mathrm{E}^{*}$ value 5.12 followed by UDRSF 3.87 and RSO15-35, 1.26. The high value for SDRSF 1585 could be due to the combined effects of enzymatic browning due to sprouting, nonenzymatic browning (maillard reaction between reducing sugars and amino acids), starch dextrination and sugar caramelization during baking (Gomez et al., 2008; Zucco et al., 2011).

\section{Texture analysis of cookies}

Texture testing is a well-established technique for evaluating the mechanical and physical properties of raw ingredients and food structure and is a property that relates to the sense of touch and can be measured easily by mechanical methods in units such as force $(\mathrm{N})$. In these studies a texturometer was used to measure the crushing, cutting and penetration force calculated at entire area of the cookie samples the results obtained are outlined Tables 8 to 10

The results showed that crushing, cutting and penetration force needed to break the cookies decreased with the incorporation of Roselle 
seed flour. The control sample had the highest value followed by $10,15,20$ and $25 \%$ respectively.

The results showed that there was significant difference $(p<0.05)$ in texture between cookies made from the composite flour blend and wheat flour as control. The difference could be as a result of decrease in gluten content in the composite flour as Roselle seed flour is added; flour with low gluten produce a low extensive gluten structure which will result in softer cookies (Ajila et al., 2008). The same decrease was recorded in cookie samples in which margarine was replaced with Roselle seed oil at $5,10,15,20,25$ and $30 \%$.

A study of viscosity of Roselle Seed oil showed the oil to have a shear thickening (dilitancy) property (Karma, et al., 2017) as such its inclusion in the product recipe could weaken the viscoelastic property of gluten in wheat flour, as gluten impacts strength to the dough (Misra et al., 1998). The results showed that there was significant difference $(\mathrm{p}<0.05)$ in texture between cookies made from substituting margarine with Roselle seed oil at varying percentages compared to the control cookie with just margarine.

The overall summary Table 8 to 10 , showed crushing force $(\mathrm{N})$ for SDRSF $15-85 \%$ ranked highest when compared to control, followed by UDRSF $15-85 \%$ and RSO 15-35\%. For cutting force $(\mathrm{N})$, UDRSF 15-85 ranked highest followed by SDRSF 15-85 and RSO 15-35. For penetration force $(\mathrm{N})$, SDRSF 15-85 ranked the highest followed by RSO 15-35 and UDRSF 15-85. The summary results showed that there was a significant difference $(p<0.05)$ between cookies made from Roselle seed flour and oil blends compared to the control.

\section{References}

Ajila, C.M., Leelavathi, K. and Prasada Rao U.J.S. (2008). Improvement of dietary fiber content and antioxidant properties in soft dough biscuits with the incorporation of mango peel powder. J Cereal Sci 48: 319-326.

Al-Wandawi, H. (2015). Organic acids composition of different parts of the medicinal plant-Roselle (Hibiscus sabdariffa), Int. J. of Bio. and Pharm. Research; 6(10): 808-813.

Al-Wandawi, H. and Farju, I.B. (1984). Roselle seed: A new protein source, Agric. Food Chem.; 32:510-512

Cissouma, A.I., Tounkara, F., Nikoo, Mehdi, Yang, N. and Xu, X. (2013). Phyico Chemical Properties and Antioxidant Activity of Roselle Seed Extracts. Adv. J. Food Sci. Technol., 5(11):1483-1489.

El-Adawy, T.A. and Khalil, A.H. (1994). Characteristics of roselle seeds as a new source of protein and lipid. Journal of Agricultural and Food Chemistry 42, 1896-1900

Emmy Hainida, K.I., Amin, I., Normah, H., Norhaizan, M.E., and Ainul, Z. (2008). Effects of defatted dried roselle (Hibiscus sabdariffa L.) Seed powder on lipid profiles of hypercholesterolemia rats. J. Sci. Food Agric. 88: 1043-1050Humbert, P., Pelletier, F., Dreno, B., Puzenat, E. and Aubin, F. (2006). Gluten Intolerance and Skin disease. Eur. J. Dermatol. 16 (1): 4-11.

Enujiugba, V.N. and Akanbi, C.T. (2008). Quality evaluation of canned fermented oil bean seed slices during ambient storage. Afr. J. Agric. Res. 5(22): 30963101.

Gomez, M., Oliete, B., Rosell, C. M., Pando, V. and Fernande, E. (2008). Studies on cake quality made of wheat-chcikpea flour blends. LWT-Food Science and Technology, 41, 1701-1709.

Karma Bako Rimamcwe and Chavan, U. D. (2016). Physical properties and nutritional potentials of Indian Roselle (Hibiscus sabdariffa L.) seeds. International Journal of Current Research. 8 (9): 38644-38648.

Karma Bako Rimamcwe and U.D. Chavan (2017). Antioxidant Activity and Nutritional Value of Roselle Seeds Flour. 
Int. J. Curr. Microbiol. App. Sci. 6(4): 2654-2663.

Karma Bako Rimamcwe, Chavan, U. D., Dalvi, U. S. and Gaikwad, R. S. (2017c). Nutritional quality of Roselle seed flour cookies. International Journal of Current Research. 9: (12): 63053-63058.

Karma Bako Rimamcwe, Chavan, U. D., Nimbalkar, C. A. and Kahar, S. P. (2017a). Rheometry of Roselle (Hibiscus Sabdariffa L.) seed oil. Int. J. Pure App. Biosci. 5 (2): 987-993.

Karma Bako Rimamcwe, Chavan, U. D., Pawar, G. H. and Gaikwad, R. S. (2017b). Nitrogen Solubility and Functional Properties of Roselle Seed Flour. Int. J. Curr. Microbiol. App. Sci. 6(8): 11311139.

Konica (2016). Konica Minolta Sensing Americas, Inc. Online source: www.sensing.konicaminolta.us

Lamacchia, C., Camarca, A., Picascia, S., Di Luccia, A. and Gianfrani, C. (2014). Cereal-based gluten-free food: how to reconcile nutritional and technological properties of wheat proteins with safety for celiac disease patients. Nutrients. 6 (2): 575-590.

Lamacchia, C., Camarca, A., Picascia, S., Di Luccia, A. and Gianfrani, C. (2014). Cereal-based gluten-free food: how to reconcile nutritional and technological properties of wheat proteins with safety for celiac disease patients. Nutrients. 6 (2): 575-590.

Mohiuddin, M.M. and Zaidi, H.R. (1975). Composition and characteristics of
Hibiscus sabdariffa seed oil. Fat, Soaps and Coating Materials 77, 488-489.

Noor Aziah, A. A., Mohamad Noor, A. Y., and Ho, L.-H. (2012). Physicochemical and organoleptic properties of cookies incorporated with legume flour. International Food Research Journal, 19, 1539-1543.

Panse, V.G. and Sukhate, P.V. (1985). Statistical methods for Agricultural Workers. $4^{\text {th }}$ ed., New Delhi.

Savage, G.P. (2001). Chemical composition of walnuts (Juglans regia L.) grown in New Zealand. Plants Food Hum. Nut. 56: 7582.

Tounkara, F., Amadou, I., Le, G and Shi, Y. (2011). Effect of boiling on the physicochemical properties of Roselle seeds (Hibiscus sabdariffa L.) cultivated in Mali, African J. of Biotechnology Vol. 10(79), pp. 181860-18166

Wani, S. H., Gull, A., Allaie, F., \& Safapuri, T. A. (2015). Effects of incorporation of whey protein concentrate on physicochemical, texture, and microbial evaluation of developed cookies. Cogent Food \& Agriculture, 1, 1092406.

Wikipedia (2008) Roselle (plant). Available online: http:// en. wikipedia.org/ wiki/Hibiscus_sabdariffa.

Zucco, F., Borsuk, Y. and Arntfield, S. D. (2011). Physical and nutritional evaluation of wheat cookies supplemented with pulse flours of different particle sizes. LWT-Food Science and Technology. doi: 10.1016/ j.lwt. 2012.02.028

\section{How to cite this article:}

Karma Bako Rimamcwe, U.D. Chavan, Ashok Kadlag and Wani, V.S. 2018. Effect of Addition of Roselle Seed Flour on Color and Textural Properties of Cookies. Int.J.Curr.Microbiol.App.Sci. 7(04): 3726-3737. doi: https://doi.org/10.20546/ijcmas.2018.704.419 